\title{
Productivity Improvement of Leather Products Industry in Bangladesh Using Lean Tools: A Case Study
}

\section{Sayid Mia MA* and Swarna NA}

Department of Leather Products Engineering, Institute of Leather Engineering and Technology, University of Dhaka, Dhaka, Bangladesh

\begin{abstract}
There is great potential for the leather industry in Bangladesh to become one of the country's major foreign exchange earners, experts say. After readymade garments (RMG), Productivity improvement can help to enrich profit of a leather products industry by minimizing excess work and developing a new method for particular operation. Now a day, productivity improvement is a popular topic for any kinds of industry. Therefore, improving productivity is one of the main concerns of leather products industries. Lean manufacturing tools are most important tools that can help to increase productivity in leather products industry. In Bangladesh, few industries use these lean tools which can be proved as a real beneficial one. Hence, this study addresses the implementation of lean principles in a leather goods manufacturing industry in order to evaluate present process cycle efficiency (PCE), lead time and productivity prior to developing an improved strategy to bring the improved PCE, productivity and to reduce the lead time. By applying lean tools in the industry at the production line for bi-fold wallet, productivity has been improved by $85.42 \%$. At the beginning state, the PCE was found $38.19 \%$ and after the implementation of lean tools, it would be $77.51 \%$ and lead time would also be reduced by $46.68 \%$ evaluated by takt time, bottleneck analysis, cause-effect analysis and Pareto analysis. The production flow was optimized by minimizing several non-value-added (NVD) activities such as bottlenecking, machine breakdown, queue time, waiting time, material handling time, etc.
\end{abstract}

Keywords: Productivity; Lean tools; PCE; Lead time; Pareto chart; Wallet production line

Abbreviations: DT: Down Time; CT: Cycle Time; UT: Up Time; VD: Value Added Time; NVD: Non Value Added Time; LT: Lead Time

\section{Introduction}

The leather sector is playing a vital role in our national economy, earning us huge amounts of export earnings. Most leather goods and footwear manufactured here are export-oriented. According to the Export Promotion Bureau (EPB), leather exports totaled USD 116.73 million in the last fiscal year 2016-2017; the amount was USD 92.50 million the previous year [1]. In the World, it is one of the leading manufacturing industries based on raw material, geographical condition, and workforce and is highly favorable for the growth of leather products industry. The demand for processed leather products is rapidly increasing in the busy World and consequently, it seems a rapid expansion of leather products industry in Bangladesh as like as other countries. It needs several production steps to produce the finished goods from raw materials. Today Higher Productivity achievement is a very important factor for the production field. With the Higher productivity, other various factors must be taken into consideration in manufacturing industries such as global competition, lead time and customer need in terms of quality and quantity $[2,3]$. Lean manufacturing is based on the Toyota Production System developed by Toyota which focuses on eliminating waste, reducing inventory, improving throughput, and encouraging employees to bring attention to problems and suggest improvements to fix those [4]. Lean manufacturing has increasingly been applied by leading manufacturing companies throughout the world. A core concept of lean manufacturing is pulling production in which the flow on the factory floor is driven by demand from downstream pulling production upstream. Some of the changes required by lean manufacturing can be disruptive if not implemented correctly and some aspects of it are not appropriate for all companies [5,6]. A lean manufacturing facility is capable of producing the product in only the sum of its value-added work content time. On the other hand, applications of lean manufacturing in the continuous process sector have been far fewer $[7,8]$. To sustain the positive growth, it is necessary to ensure the proper utilization of resources. Financial growth of any industry largely depends on minimizing excess work and productivity improvement. This study was masterful with some specific objectives which were to identify, quantify and to reduce the non-value added (NVD) activities and time towards the exalted Process Cycle Efficiency (PCE) and therefore to reduce the lead time.

\section{Methodology}

The primary data was collected from personal observations of researchers of bi-fold wallet production lines at different production stages from a leading export-oriented leather products industry in Bangladesh. The secondary data was taken through the internet, books, journals, related studies and other sources of information. The methodology of carrying out this project work is divided into the following steps. In each of the steps, lean tools have been used which have been discussed in each section further.

Process mapping $\longrightarrow$ Take time calculating Lead $\longrightarrow$ time counting $\longrightarrow$ Bottleneck analysis

Cause-effect analysis $\longrightarrow$ Introducing time reducing technique $\rightarrow$ Results

\section{Existing Process Mapping}

A process map is a planning and management tool that visually

*Corresponding author: Sayid Mia MA, Department of Leather Products Engineering, Institute of Leather Engineering and Technology, University of Dhaka, Dhaka-1209, Bangladesh, Tel: +8801674772545; E-mail: emsayid@gmail.com

Recieved March 26, 2018; Accepted May 16, 2018; Published May 24, 2018

Citation: Sayid Mia MA, Swarna NA (2018) Productivity Improvement of Leather Products Industry in Bangladesh Using Lean Tools: A Case Study. J Entrepren Organiz Manag 7: 234. doi: 10.4172/2169-026X.1000234

Copyright: (๑ 2018 Sayid Mia MA, et al. This is an open-access article distributed under the terms of the Creative Commons Attribution License, which permits unrestricted use, distribution, and reproduction in any medium, provided the original author and source are credited. 
Citation: Sayid Mia MA, Swarna NA (2018) Productivity Improvement of Leather Products Industry in Bangladesh Using Lean Tools: A Case Study. J Entrepren Organiz Manag 7: 234. doi: 10.4172/2169-026X.1000234

Page 2 of 8

describes the flow of work. Process maps show a series of events that produce an end result. It shows who and what is involved in a process and can be used in any business or organization and can reveal areas where a process should be improved (Figure 1 and 2).

\section{Takt Time Analysis}

Takt-time is the unit of time in which a product must be produced (supply rate) in order to match the rate at which that product is needed (demand rate) [9]. It is calculated by dividing the total available time per day by the daily customer demand.
Takt time $=$ Available work time $/$ Customers demand

Available production time $=(7$ hours 45 minutes $) \times 8$

$$
\begin{aligned}
& =465 \times 8) \text { minutes } \\
& =3720 \text { minutes } .
\end{aligned}
$$

Customer's demand is 50 pcs of Double wallet.

Takt Time Formula $=3720 / 50=74.4$ minutes/wallet.

In this research, after receiving order, the production process

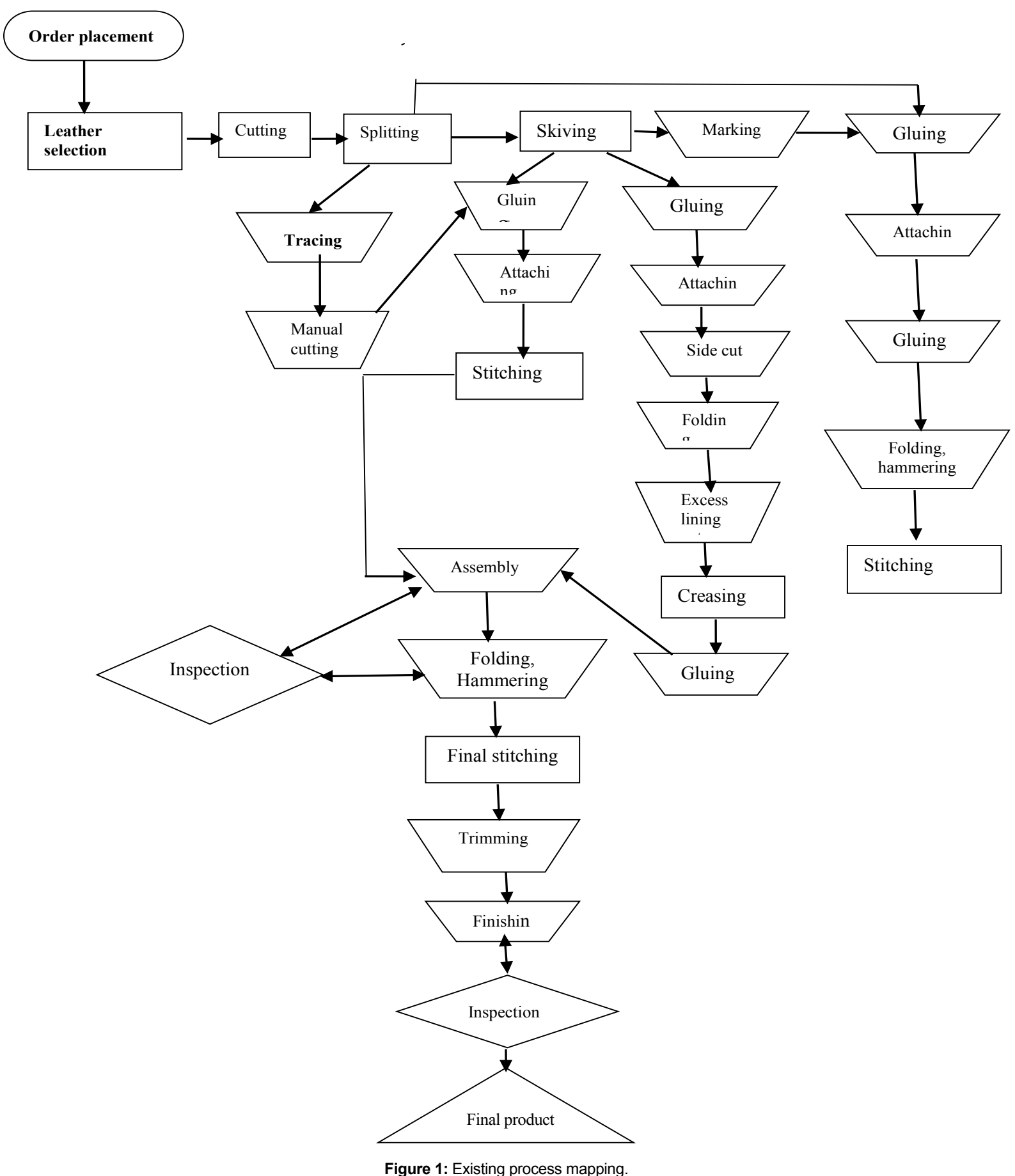






Figure 2: Proposed process mapping. 
Citation: Sayid Mia MA, Swarna NA (2018) Productivity Improvement of Leather Products Industry in Bangladesh Using Lean Tools: A Case Study. J Entrepren Organiz Manag 7: 234. doi: 10.4172/2169-026X.1000234

Page 4 of 8

started and the final product (Double wallet) was delivered to the customer. The factory had 8 days to deliver 50 pcs of wallet, of which 1 day was off-day. The factory has a 9-hour workday for its workers and staffs, of which 01 hour is allocated lunch break, 15 minutes is wasted in the startup process in the morning.

\section{Data Analysis}

With the help of table the Data analysis of Existing Cycle time analysis of bio-fold wallet production line has been explained here (Table 1).

\begin{tabular}{|c|c|c|c|c|c|c|c|c|}
\hline No & Operation name & $\begin{array}{l}\text { Average cycle } \\
\text { time(sec) }\end{array}$ & $\begin{array}{c}\text { No. of } \\
\text { workers }\end{array}$ & $\begin{array}{c}\text { Waiting time in } \\
\text { seconds }\end{array}$ & $\begin{array}{c}\text { Total waiting } \\
\text { time }\end{array}$ & $\begin{array}{l}\text { Process gap } \\
\text { time (sec) }\end{array}$ & $\begin{array}{c}\begin{array}{c}\text { No. of pcs of } \\
\text { work }\end{array} \\
\end{array}$ & $\begin{array}{l}\text { Total time } \\
\quad(\mathrm{sec})\end{array}$ \\
\hline 1 & Cutting leather, lining, net & 6 & 4 & & & & 1800 & 10800 \\
\hline 2 & Splitting leather & 4 & 1 & & & & 750 & 2823 \\
\hline 3 & Skiving & 12 & 1 & & & 86400 & 250 & 3000 \\
\hline 3 & Marking outer top & 50 & 1 & & & & 50 & 2500 \\
\hline 4 & Foam attaching on lining & 56 & 2 & & & & 50 & 2800 \\
\hline 5 & Excess lining cutting & 20 & 1 & 16 & 800 & & 50 & 1000 \\
\hline 6 & Gluing outer top & 25 & 1 & 25 & 1250 & & 50 & 1250 \\
\hline 7 & Lining with foam attaching on outer top & 9 & 1 & 19 & 950 & & 50 & 450 \\
\hline 8 & Adhesive applying on top side & 10 & 1 & 18 & 900 & & 50 & 500 \\
\hline 9 & Folding, hammering & 45 & 1 & & & & 50 & 2250 \\
\hline 10 & Stitching & 10 & 1 & & & 293 & 50 & 500 \\
\hline 11 & Gluing center piece & 20 & 1 & & & 293 & 100 & 2000 \\
\hline 12 & Center piece attaching on lining & 18 & 1 & 2 & 200 & & 100 & 1800 \\
\hline 13 & Stitching & 10 & 1 & 40 & 4000 & & 100 & 1000 \\
\hline 14 & Gluing on step pocket & 10 & 1 & & & 293 & 360 & 3600 \\
\hline 15 & Lining attaching & 6 & 1 & 4 & 1440 & & 360 & 2160 \\
\hline 16 & Top side folding, hammering & 40 & 2 & & & & 360 & 7200 \\
\hline 17 & Gluing on stamp pocket & 12 & 1 & 16 & 2400 & & 150 & 1800 \\
\hline 18 & Lining attaching & 6 & 1 & 22 & 3300 & & 150 & 900 \\
\hline 19 & Side cut for folding & 5 & 1 & 23 & 3450 & & 150 & 750 \\
\hline 20 & Folding, hammering excess lining cutting & 45 & 1 & & & & 150 & 6750 \\
\hline 21 & Inspection & 10 & 1 & 35 & 5250 & & 150 & 1500 \\
\hline 22 & Creasing & 20 & 1 & & & 3750 & 150 & 3000 \\
\hline 23 & Window pocket tracing & 18 & 1 & & & & 50 & 900 \\
\hline 24 & Manual cutting & 88 & 1 & & & & 50 & 4400 \\
\hline 25 & Gluing on window pocket & 15 & 1 & 73 & 3650 & & 50 & 750 \\
\hline 26 & Net attaching on window pocket & 10 & 1 & 78 & 3900 & & 50 & 500 \\
\hline 27 & Side cut for folding & 5 & 1 & 85 & 4250 & & 50 & 250 \\
\hline 28 & Top side folding, hammering & 23 & 1 & 67 & 3350 & & 50 & 1150 \\
\hline 29 & Inspection & 18 & 1 & 72 & 3600 & & 50 & 900 \\
\hline 30 & Creasing & 20 & 1 & & & 350 & 50 & 1000 \\
\hline 31 & Gluing on both sides of step pocket & 5 & 1 & & & & 360 & 1800 \\
\hline 32 & Assembling 3 step pockets & 25 & 1 & & & & 120 & 3000 \\
\hline 33 & Stamp pocket placing & 12 & 1 & 17 & 850 & & 120 & 1440 \\
\hline 34 & Excess lining cutting & 20 & 1 & 11 & 550 & & 50 & 1000 \\
\hline 35 & Stitching & 10 & 1 & & & 4050 & 50 & 500 \\
\hline 36 & Assembling 2 step pockets & 15 & 1 & & & & 50 & 750 \\
\hline 37 & Window pocket placing & 20 & 1 & & & & 50 & 1000 \\
\hline 38 & Excess lining cutting & 22 & 1 & & & & 50 & 1100 \\
\hline 39 & Stitching & 5 & 1 & & & 2850 & 50 & 250 \\
\hline 40 & 1step pocket,1 cut pocket attaching & 40 & 2 & & & 405 & 100 & 4000 \\
\hline 41 & Joining window and 1 cut pocket by stitching & 10 & 1 & 17 & 850 & & 50 & 500 \\
\hline 42 & Assembling asther-1 & 50 & 1 & & & 285 & 50 & 2500 \\
\hline 43 & Assembling asther-2 & 50 & 1 & & & 300 & 50 & 2500 \\
\hline 44 & Joining by stitching & 10 & 1 & & & 2350 & 50 & 500 \\
\hline 45 & Attaching asther on outer top & 55 & 1 & & & & 50 & 2750 \\
\hline 46 & Gluing three sides of outer & 20 & 1 & 35 & 1750 & & 50 & 1000 \\
\hline 47 & Folding, hammering & 62 & 1 & & & & 50 & 3100 \\
\hline 48 & Final stitching & 12 & 1 & 50 & 2500 & & 50 & 600 \\
\hline 49 & Trimming, thread cutting & 25 & 1 & 37 & 1850 & & 50 & 1250 \\
\hline 50 & Final checking & 50 & 1 & 12 & 600 & & 50 & 2500 \\
\hline \multirow[t]{2}{*}{51} & Packaging & 30 & 1 & 32 & 1600 & & 50 & 1500 \\
\hline & Total & 1244 & & & 53240 & 101619 & & 102373 \\
\hline
\end{tabular}

Table 1: Existing cycle time analysis of bio-fold wallet production line. 
Citation: Sayid Mia MA, Swarna NA (2018) Productivity Improvement of Leather Products Industry in Bangladesh Using Lean Tools: A Case Study. J Entrepren Organiz Manag 7: 234. doi: 10.4172/2169-026X.1000234

Page 5 of 8

\section{Present process cycle efficiency}

PCE is measured as the percentage of ration of VD time and lead time, where lead time is the summation of VD and NVD time [10]. PCE is a measure of the relative efficiency in a process - it represents the percentage of value add time (changing form, fit, function) of a product down the critical path.

Value added time $=102373$ seconds $=28.44 \mathrm{hrs}$

Non-value-added time =Set-up time+Total waiting time+Total process gap time

$$
=(10800+53240+101619) \text { seconds }=165659 \text { seconds }=46.02 \mathrm{hrs}
$$

Lead time $\quad=$ Value added time+Non-value-added time

$=(102373+165659)$ seconds $=268032$ seconds $=74.45 \mathrm{hrs}$

No. of worker $=14$

Productivity $=0.048$

PCE $\quad=($ Customer Value Added Time $\div$ Process Lead Time $) \times 100 \%$

$$
=(102373 \div 268032) \times 100 \%=38.19 \% \text {. }
$$

\section{Bottleneck analysis}

By definition, a bottleneck is a phenomenon where the competency of a complete system or line is restricted or limited by a single or limited number of components or resources and analysis of such event is called as Bottleneck analysis. Hence, Bottleneck analysis is nothing but the identification which part/machine of the manufacturing process/line limits the overall output and focuses on improvement the performance of that part/machine of the process/line [11]. Bottleneck analysis is usually done along with the Time Study Method. From the process map and cycle time analysis table, we can calculate the time required in each path.
Path-1: Splitting-Skiving-Making-Gluing-Attaching-Gluing-FoldingStitching $=297$ seconds

Path-2: Splitting-Gluing-Attaching-Stitching $=106$ seconds

Path-3: Splitting-Skiving-Gluing-Attaching-Side Cut-Folding-Excess lining cut-Creasing $=270$ seconds

Path-4: Splitting-Skiving-Gluing-Attaching-Side Cut-Folding-Excess lining cut-Creasing $=270$ seconds

Path-5: Splitting-Tracing-Manual Cutting-Gluing-Attaching-Side Cut-Folding-Creasing $=576$ seconds

Path-6: Creasing-Gluing-Assembly-Folding-Final Stitch-TrimmingFinishing-Inspection-Final product $=736$ seconds

Here, Path- 6 takes the longest period of time to complete one cycle. So, the Bottleneck is Path-6.

\section{Cause-effect analysis}

As the Ishikawa diagram is prior to any data analysis, every possible cause is taken into consideration. Although it was originally developed as a quality control tool, can be used just as well in other ways. For instance, can be used to-Discover the root cause of a problem, Uncover bottlenecks in your processes, Identify where and why a process isn't working etc.

Since we found that lead time is 88.8 minutes/wallet, whereas, take time is 93 minutes/wallet; this is a serious problem that may cause huge delay in delivery. Therefore, we used Fishbone Diagram to find out possible cause behind this which is shown below (Figure 3).

\section{Pareto analysis}

It is a statistical technique in decision making that is used for selection of a limited number of tasks that produce significant overall

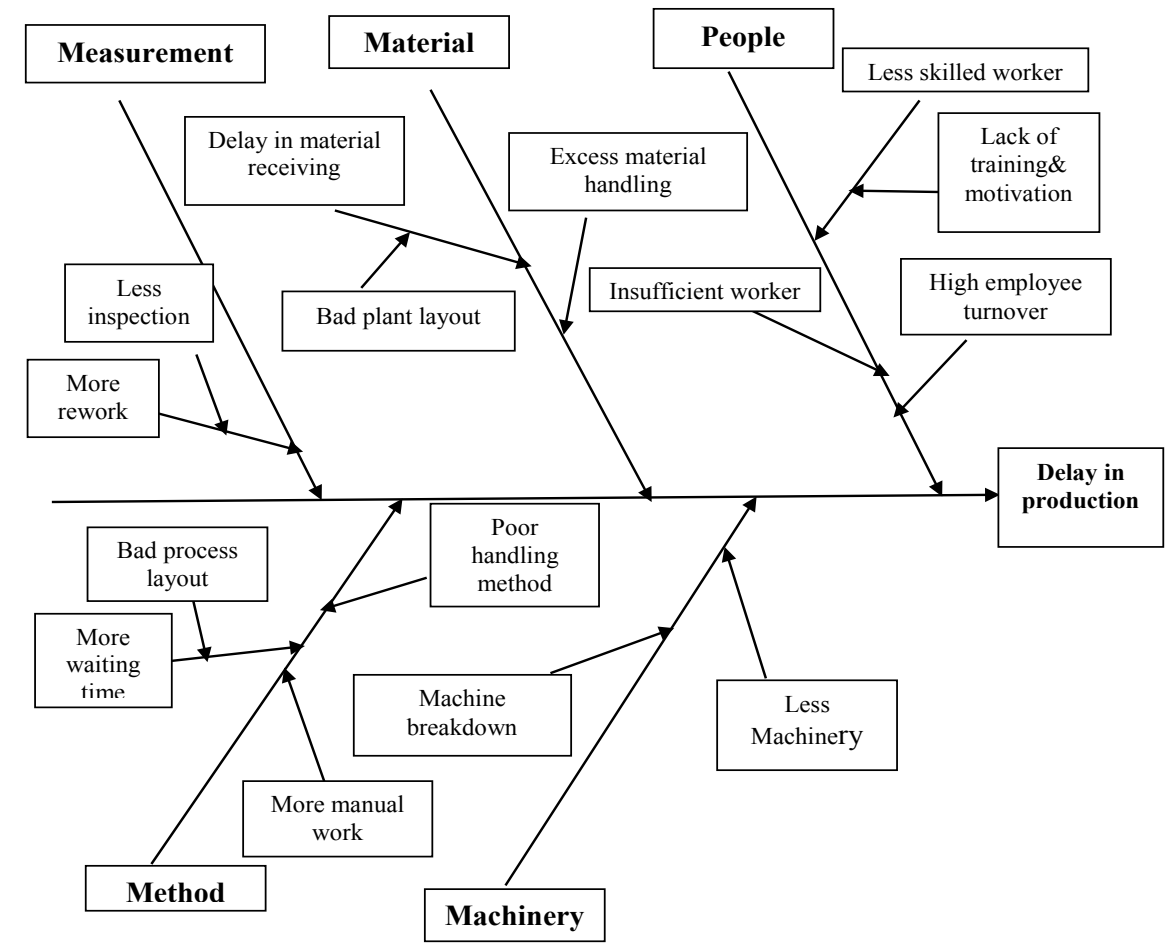

Figure 3: Cause-effect analysis. 
Citation: Sayid Mia MA, Swarna NA (2018) Productivity Improvement of Leather Products Industry in Bangladesh Using Lean Tools: A Case Study. J Entrepren Organiz Manag 7: 234. doi: 10.4172/2169-026X.1000234

Page 6 of 8

effect. It uses the Pareto principle - the idea that by doing $20 \%$ of work, $80 \%$ of the advantage of doing the entire job can be generated [12]. The Pareto Principle also known as the " $80 / 20$ Rule" which is the idea that $20 \%$ of causes generate $80 \%$ of results [13-15]. In this study, by using this tool it was tried to find out the $20 \%$ of causes that is generating $80 \%$ NVD activities. This tool focuses on the most damaging causes on a project.
In this essence, the application of the Pareto chart consisting of causes for downtime or NVD activities along the $\mathrm{X}$ axis while the $\mathrm{Y}$ axis represents the cumulative percentage of downtime. Most of the NVD activities were documented on sewing, pre-lasting, post-lasting and finishing steps where these were frequently observed due to different causes. The highest frequency of NVD activities that derived the down time were found for mainly Needle and threads breakage while the lowest frequency was varied (Figure 4 and Table 2).

\begin{tabular}{|c|c|c|c|c|c|c|c|c|}
\hline No & Operation name & $\begin{array}{l}\text { Average cycle } \\
\text { time (sec) }\end{array}$ & $\begin{array}{l}\text { No. of } \\
\text { workers }\end{array}$ & $\begin{array}{l}\text { Waiting } \\
\text { time (sec) }\end{array}$ & $\begin{array}{l}\text { Total waiting } \\
\text { time }\end{array}$ & $\begin{array}{l}\text { Process gap } \\
\text { time (sec) }\end{array}$ & $\begin{array}{l}\text { No. of pcs } \\
\text { of work }\end{array}$ & $\begin{array}{l}\text { Total } \\
\text { time }(\mathrm{sec})\end{array}$ \\
\hline 1 & Cutting leather, lining, net & 6 & 4 & & & & 1800 & 10800 \\
\hline 2 & Splitting leather & 4 & 1 & & & & 750 & 2823 \\
\hline 3 & Skiving & 12 & 1 & & & & 250 & 3000 \\
\hline 4 & Marking outer top & 50 & 2 & & & & 50 & 2500 \\
\hline 5 & Foam attaching on lining & 56 & 2 & & & & 50 & 2800 \\
\hline 6 & Excess lining cutting & 20 & 1 & 16 & 800 & & 50 & 1000 \\
\hline 7 & Gluing on outer top & 25 & 1 & & & & 50 & 1250 \\
\hline 8 & $\begin{array}{l}\text { Lining \& foam attaching on outer top\& } \\
\text { gluing on top side }\end{array}$ & 19 & 1 & 6 & 300 & & 50 & 950 \\
\hline 9 & Folding, hammering & 45 & 1 & & & & 50 & 2250 \\
\hline 10 & Stitching & 10 & 1 & & & 237 & 50 & 500 \\
\hline 11 & Gluing center piece & 20 & 1 & & & 237 & 100 & 2000 \\
\hline 12 & Center piece attaching on lining & 18 & 1 & 2 & 200 & & 100 & 1800 \\
\hline 13 & Stitching & 10 & 1 & 10 & 1000 & & 100 & 1000 \\
\hline 14 & Gluing on step pocket & 10 & 1 & & & 237 & 360 & 3600 \\
\hline 15 & Lining attaching & 6 & 1 & 4 & 1440 & & 360 & 2160 \\
\hline 16 & Top side folding, hammering & 40 & 1 & & & & 360 & 14400 \\
\hline 17 & Gluing on stamp pocket & 12 & 1 & & & 237 & 150 & 1800 \\
\hline 18 & Lining attaching $\&$ side cut & 11 & 1 & & & & 150 & 1650 \\
\hline 19 & Folding, hammering excess lining cutting & 45 & 1 & & & & 150 & 6750 \\
\hline 20 & Inspection & 10 & 1 & 19.36 & 2905 & & 150 & 1500 \\
\hline 21 & Creasing & 20 & 1 & & & & 150 & 3000 \\
\hline 22 & Window pocket tracing & 18 & 1 & & & & 50 & 900 \\
\hline 23 & Manual cutting & 88 & 2 & & & & 50 & 4400 \\
\hline 24 & $\begin{array}{l}\text { Gluing on window pocket, net attaching } \\
\& \text { side cut }\end{array}$ & 30 & 1 & 14 & 700 & & 50 & 1500 \\
\hline 25 & Top side folding, hammering \& inspection & 41 & 1 & 3 & 150 & & 50 & 2050 \\
\hline 26 & Creasing & 20 & 1 & 24 & 1200 & & 50 & 1000 \\
\hline 27 & $\begin{array}{l}\text { Gluing on both sides of step pocket\& } \\
\text { assembling } 3 \text { step pockets }\end{array}$ & 40 & 1 & & & & 120 & 4800 \\
\hline 28 & $\begin{array}{l}\text { Stamp pocket placing \& excess lining } \\
\text { cutting }\end{array}$ & 33 & 1 & 7 & 840 & & 120 & 3960 \\
\hline 29 & Stitching & 10 & 1 & 30 & 3600 & & 120 & 1200 \\
\hline 30 & Assembling 2 step pockets & 15 & 1 & & & & 50 & 750 \\
\hline 31 & Window pocket placing & 20 & 1 & & & & 50 & 1000 \\
\hline 32 & Excess lining cutting & 22 & 1 & & & & 50 & 1100 \\
\hline 33 & Stitching & 10 & 1 & 12 & 600 & & 50 & 500 \\
\hline 34 & 1step pocket, 1 cut pocket attaching & 40 & 2 & & & & 100 & 4000 \\
\hline 35 & $\begin{array}{l}\text { Joining window and } 1 \text { cut pocket by } \\
\text { stitching }\end{array}$ & 10 & 1 & 17 & 850 & & 50 & 500 \\
\hline 36 & Assembling asther-1 & 50 & 1 & & & & 50 & 2500 \\
\hline 37 & Assembling asther-2 & 50 & 1 & & & & 50 & 2500 \\
\hline 38 & Joining by stitching & 10 & 1 & 40 & 2000 & & 50 & 500 \\
\hline 39 & Attaching asther on outer top & 55 & 2 & & & & 50 & 1375 \\
\hline 40 & Gluing three sides of outer & 20 & 1 & 15 & 750 & & 50 & 1000 \\
\hline 41 & Folding, hammering & 62 & 1 & & & & 50 & 3100 \\
\hline 42 & Final stitching, thread cutting & 45 & 1 & 17 & 850 & & 50 & 600 \\
\hline 43 & Final checking & 50 & 1 & 12 & 600 & & 50 & 2500 \\
\hline \multirow[t]{2}{*}{44} & Packaging & 30 & 1 & 32 & 1600 & & 50 & 1500 \\
\hline & & Total $=1218$ & & & Total=20385 & Total $=948$ & & Total $=110768$ \\
\hline
\end{tabular}

Table 2: Cycle time analysis for proposed way of bio-fold wallet production line. 


\section{Pareto Chart}

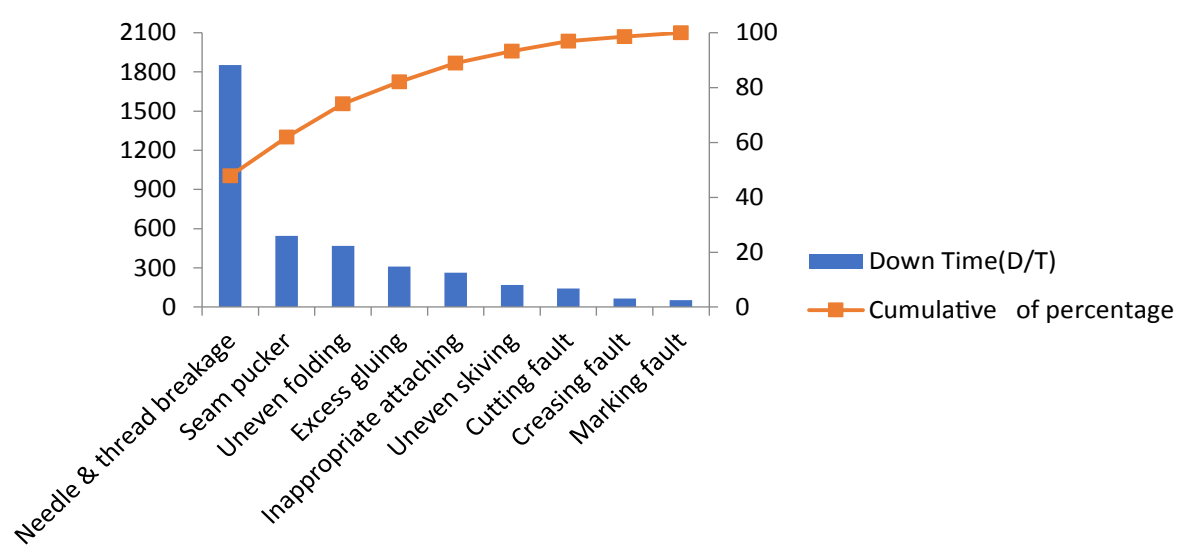

Figure 4: Pareto Chart of Bio-fold wallet production line.

\section{Process cycle efficiency after using lean tools}

Value added time $\quad=110768$ seconds $=30.8 \mathrm{hrs}$

Non-value-added time $=$ Set-up time + Total waiting time + Total process gap time

$$
\begin{aligned}
& =(10800+20385+948) \text { seconds }=32133 \\
& \text { seconds }=8.93 \mathrm{hrs}
\end{aligned}
$$

So, Lead time $=$ Value added time + Non-value-added time

seconds $=39.69 \mathrm{hrs}$

$$
=(110768+32133) \quad \text { seconds }=142901
$$

$\begin{array}{ll}\text { No. } \text { of worker } & =14 \\ \text { Productivity } & =0.089\end{array}$

Productivity improvement $=(0.089-.048) / 0.048 \times 100 \%=85.4 \%$

PCE $=($ Customer Value Added Time $\div$ Process

Lead Time) $\times 100 \%$

\section{Existing productivity}

Value added time

$$
=102373 \text { seconds or, } 28.43 \mathrm{hrs}
$$

Non-value-added time

Lead time

$=165659$ seconds or $46.02 \mathrm{hrs}$

Productivity

$=268032$ seconds or $74.45 \mathrm{hrs}$

Process cycle efficiency

$$
=0.048
$$

\section{Productivity after using lean tools}

Value added time

Non-value-added time

Lead time

Productivity

Process cycle efficiency
$=110768$ seconds or $30.77 \mathrm{hrs}$

$=32133$ seconds or $8.92 \mathrm{hrs}$

$=142901$ seconds or $39.69 \mathrm{hrs}$

$=.089$

$=77.51 \%$.

\section{Results}

Productivity improvement $\quad=(.089-.048) / .048 \times 100 \%=85.42 \%$

Lead time reduction $\quad=(74.45-39.69) / 74.45 \times 100 \%=46.69 \%$

Value added time increased $=(30.77-28.43) / 28.43 \times 100 \%=8.23 \%$

Non- value-added time reduction $=(46.02-8.93) / 46.02 \times 100 \%=80.59 \%$

PCE improvement $\quad=(77.51-38.19) \%=39.35 \%$

\section{Conclusion}

The leather products industry is one of the key export-earning sectors in Bangladesh. Productivity improvement is a crucial matter in this industry. The profit earning of this industry totally rely on productivity improvement. The implementation of the lean concept in the leather products industry is primarily focused in order to reduce lead time and improve PCE. This model paves the way to ease implementation of lean concepts in leather products industry not only in Bangladesh but around the globe.

\section{References}

1. Hossain L, Sarker SK, Khan MS (2017) Evaluation of Present and Future Wastewater Impacts of Leather Industries in Bangladesh. Environmental Development.

2. Sayid Mia MA, Nur-E-Alam M, Ahmad F, Kamal Uddin M (2017) Footwear Industry in Bangladesh: Implementation of Six Sigma Methodology. Ind Eng Manage 6: 211.

3. Sayid Mia MA, Nur-E-Alam M, Lutfor Rahman M, Kamal Uddin M (2017) Footwear Industry in Bangladesh: Reduction of Lead time by using Lean Tools. JECET 6: 251-259.

4. Womack JP, Jones DT, Roos D (1991) The Machine that Changed the World. Harper Collins Publishers.

5. Hobbs DP (2004) Lean Manufacturing Implementation: A Complete Execution Manual for any Size Manufacturer. J Ross Publishing.

6. Sayid Mia MA, Nur-E-Alam M, Kamal Uddin M (2017) Court Shoe Production Line: Improvement of Process Cycle Efficiency by using Lean Tools. Leather and Footwear Journal.

7. Abdullah F, Rajgopal J (2003) Lean Manufacturing in the Process Industry Proceedings of the IIE Research Conference, pp: 1-6.

8. Sayid Mia MA, Nur-E-Alam M, Ahmad F, Kamal Uddin M (2017) Implementation of Lean Manufacturing Tools in Footwear Industry of Bangladesh. Aspects Min Miner Sci. 
Citation: Sayid Mia MA, Swarna NA (2018) Productivity Improvement of Leather Products Industry in Bangladesh Using Lean Tools: A Case Study. J Entrepren Organiz Manag 7: 234. doi: 10.4172/2169-026X.1000234

Page 8 of 8

9. Frandson A, Berghede K, Tommelein ID (2014) TAKT-Time Planning and the Last Planner. Production, Planning and Control; Proceedings IGLC-22, Oslo, Norway.

10. Zhen Y (2011) Food safety and lean Six Sigma Model. University of Central Missouri.

11. Leporis M, Kralova Z (2010) A simulation Approach to Production Line Bottleneck Analysis. International Conference in Cybernetics and Informatics.
12. Pareto V, Trattato di Sociologia GF (1935) The Mind and Society.

13. Kimber RJ, Grenier RW, Heldt JJ (1997) Quality Management Handbook. Marcel Dekker.

14. Dyche J (2001) The CRM Handbook: A Business Guide to Customer Relationship Management.

15. Arthur LJ (1992) Rapid Evolutionary Development-Requirements, Prototyping and Software Creation. John Wiley and Sons 2: 43-44. 